\title{
Functional Properties of Proteins Isolated From Industrially Produced Sunflower Meal
}

\author{
Petia Ivanova ${ }^{\mathrm{a}}$, Vesela Chalova ${ }^{\mathrm{a}^{*}}$, And Lidia Koleva ${ }^{\mathrm{a}}$ \\ ${ }^{\mathrm{a}}$ University of Food Technologies, Department of Biochemistry and Molecular Biology, 26 Maritza Blvd., \\ Plovdiv 4002, Bulgaria \\ ${ }^{*}$ Corresponding author \\ veselachalova@gmail.com \\ TEL: 035932603855
}

Received: 15 December 2013; Published online: 18 October 2014

\begin{abstract}
Protein isolate 1 (PI1) and protein isolate 2 (PI2) were prepared from industrially produced sunflower meal by using isoelectric and ethanol precipitation respectively. The water absorption capacity of PI1 was 6 times higher than that of PI2 and was significantly reduced by the presence of $0.03 \mathrm{M}$ and 0.25 $\mathrm{M} \mathrm{NaCl}$. Oil absorption capacity of both protein isolates was not influenced by $\mathrm{NaCl}$ supplementation. Foam capacity of PI1 and PI2 was pH-dependent. While the foam capacity of both isolates was improved by either $0.03 \mathrm{M}$ or $0.25 \mathrm{M} \mathrm{NaCl}$, the foam stability was negatively influenced by the addition of $\mathrm{NaCl}$ at all $\mathrm{pH}$ values with except for $\mathrm{pH}$ 4. Emulsifying activity of PI1 and PI2 was lowest at $\mathrm{pH}$ 4. The emulsions exhibited relatively high stability $(>90 \%)$ under all studied conditions. Knowledge of the influence of $\mathrm{pH}$ and boundary concentrations of $\mathrm{NaCl}$ on the functionality of sunflower meal protein isolates could be beneficial for their future potential application in food industry.
\end{abstract}

Keywords: Sunflower protein isolates; Functionality; Sodium chloride; pH

\section{Introduction}

Plant proteins are good sources of essential amino acids for vegetarians and an alternative food for humans where animal protein is either expensive or scarce because of unfavorable natural factors. Sunflower meal is a by-product of oil production with high protein content $(30 \%-$ $50 \%$ ) (Bau, Mejean, Debry, \& Mohtadinia, 1983; Damodaran, 1997). However, its common utilization as a feed supplement in animal nutrition is limited due to relatively high fibre content (Senkoylu \& Dale, 2006; Raza, Ashraf, Pasha, \& Latif, 2009). The application of the sunflower meal as an unconventional protein source for human consumption is an alternative approach which could lead to more complete and efficient use of this by-product.

Copyright (C)2014 ISEKI-Food Association (IFA)
The utilization of plant protein isolates in the food industry depends on their functional properties since they affect the formulation, preparation and quality of food products (Mahajan \& Dua, 2002). For example, protein isolates with high water- and oil absorption capacity are more desired for the preparation of meat derived products and bread, while protein isolates with good emulsifying and foaming properties are preferably applied in salad dressings, soups and frozen products (Ahmedna, Prinyawiwatkul, \& Rao, 1999; Kanu et al., 2007).

Functional properties of proteins are determined by their size, shape, and structure of molecules, amino acid content and sequence (Damodaran, 1997). They also depend on extrinsic factors such as $\mathrm{pH}$, salt concentrations, temperature, chemical reagents and interactions with other food 
204 | Ivanova et al.

components (Kinsella, Damodaran, \& German, 1985). Among them, the impact of salts on protein functionality is of great interest since the system protein-water-salt is a major determinant of the quality and the consumer acceptance of food products (Aremu, Olaofe, Akintayo, \& Adeyeye, 2008; Andualem \& Gessesse, 2013). The $\mathrm{pH}$ of the food system affects hydrophobicity, net charge and electrostatic repulsive forces of proteins thus modulating their interactions and functionality.

The choice of a method for preparation may also result in protein isolates with different functionality. Organic solvents are commonly used to prepare high purity protein samples (MartínezMaqueda, Hernández-Ledesma, Amigo, Miralles, \& Gómez-Ruiz, 2013). However, they are not appropriate for food applications. The extraction/precipitation of proteins with alcoholic or aqueous solutions is less toxic and more advantageous when used in the food industry but may also lead to altered functionality of the protein isolates (Moure, Sineiro, Dominguez, \& Parajo, 2006).

Most published studies on sunflower meal proteins have been performed under mild laboratory conditions where no change of the native structure and functions of the proteins occurred (Pawar, Patil, Sakhale, \& Agarkar, 2001; González-Pérez et al., 2004; Pickardt et al., 2009). However, sunflower proteins obtained from industrially produced meal may have different functional characteristics due to the impact of the technological parameters of oil production and sunflower seed pre-treatment. The protein isolates from industrially obtained sunflower meal, however, are of a higher practical interest since they lead to a better and more efficient use of this by-product. Knowledge of the influence of $\mathrm{pH}$ and boundary concentrations of $\mathrm{NaCl}$ on the functionality of sunflower meal protein isolates could facilitate their potential application in food industry. The purpose of this research was to explore water- and oil absorption capacity, foaming and emulsifying properties of proteins isolated from industrially produced sunflower meal by using isoelectric or ethanol precipitation. The functional properties were studied at different $\mathrm{pH}$ in the presence of two levels of $\mathrm{NaCl}(0.03 \mathrm{M}$ and $0.25 \mathrm{M})$ and compared to those when no salt was added to the system.

\section{Materials and Methods}

\subsection{Preparation of protein isolates}

Two protein isolates were prepared from sunflower meal provided by a local oil factory, as described by Ivanova, Koleva, Tziporkov, and Pishtiyski (2011) and Ivanova, Chalova, Koleva, Pishtiyski, and Perifanova-Nemska (2012). Briefly, $100 \mathrm{~g}$ sunflower meal (average particle size $1.02 \mathrm{~mm}$ ) were suspended in $300 \mathrm{ml} 10 \%$ $\mathrm{NaCl}(\mathrm{pH}$ 6) and the volume was subsequently adjusted to $1000 \mathrm{ml}$ with $10 \% \mathrm{NaCl}(\mathrm{pH} 6)$. The suspension was incubated at $40^{\circ} \mathrm{C}$ for $60 \mathrm{~min}$ to extract proteins. Solid phase was separated by filtration. Protein isolate 1 (PI1) was prepared by isoelectric precipitation of the extracted proteins. After adjusting the $\mathrm{pH}$ to 2.5 with 6 $\mathrm{N} \mathrm{HCl}$, the protein precipitate was collected by centrifugation at $5000 \mathrm{x} \mathrm{g}$ for $15 \mathrm{~min}$ (MPW251, Med. Instruments, Poland), washed three times with $100 \mathrm{ml} \mathrm{HCL} \mathrm{(pH} \mathrm{2.5)} \mathrm{and} \mathrm{dried} \mathrm{by}$ lyophilization for $24 \mathrm{~h}$ (Lyovac GT2, LeyboldHeraeus, Germany). Protein isolate 2 (PI2) was obtain by addition of $1250 \mathrm{ml} 96 \%$ ethanol to 500 $\mathrm{ml}$ protein extract. Protein precipitate was collected by centrifugation at $5000 \mathrm{x}$ g for $15 \mathrm{~min}$, washed three times with $100 \mathrm{ml} 96 \%$ ethanol and dried overnight at $40^{\circ} \mathrm{C}$ in an oven (SLW 53, PolEko Aparatura, Poland).

\subsection{Determination of water- and oil absorption capacity}

Water absorption capacity (WAC) was determined as described by Rodríguez-Ambriz, Martínez-Ayala, Millán, and Dávila-Ortíz (2005). Each protein sample (100 mg) was mixed with $1 \mathrm{ml}$ distilled water and vortexed (Advanced Vortex Mixer - ZX3, VELP Scientifica, Usmate (MB), Italy) for $30 \mathrm{~s}$. The resulted suspension was incubated at room temperature for $30 \mathrm{~min}$, centrifuged for $20 \mathrm{~min}$ at $1800 \mathrm{x} \mathrm{g}\left(22^{\circ} \mathrm{C}\right)$ and the supernatant was decanted for $10 \mathrm{~min}$ at $45^{\circ}$ angle. WAC was calculated by dividing the weight of the absorbed water ( $g$ ) by the weight of the protein sample $(\mathrm{g})$.

IJFS |October 2014 | Volume 3 |pages 203-212 
Functional properties of sunflower meal protein isolates |205

Oil absorption capacity (OAC) was determined by the method of Lin and Zayas (1987). Each protein sample $(100 \mathrm{mg})$ was mixed with $1 \mathrm{ml}$ sunflower oil and vortexed (Advanced Vortex Mixer - ZX3, VELP Scientifica, Usmate (MB), Italy) for $30 \mathrm{~s}$. The emulsion was incubated at room temperature $\left(22^{\circ} \mathrm{C}\right)$ for $30 \mathrm{~min}$ and subsequently centrifuged at $13600 \mathrm{x} \mathrm{g}$ for $10 \mathrm{~min}$. The supernatant was decanted and drained for $20 \mathrm{~min}$ at $45^{\circ}$ angle. OAC was calculated by dividing the weight of the absorbed oil (g) by the weight of the protein sample $(\mathrm{g})$.

\subsection{Foam capacity and stability}

Foam capacity and stability were determined as described by Sze-Tao and Sathe (2000) with some modification. An aliquot of $20 \mathrm{ml}$ protein solution $(0.5 \mathrm{mg} / \mathrm{ml})$ was whipped for $70 \mathrm{~s}$ in a graduated cylinder by hand. The foam stability was defined as the volume of the foam that remained after $60 \mathrm{~min}$ at room temperature $\left(22^{\circ} \mathrm{C}\right)$ and was expressed as a percentage of the initial foam volume. Foam capacity was determined by volume increase (\%) imediately after whipping and was calculated by the formula $\left(\mathrm{V}_{2}-\mathrm{V}_{1}\right) / \mathrm{V}_{1} \mathrm{x}$ 100 where $V_{2}$ is the volume of protein solution after whipping and $V_{1}$ is the volume of solution before whipping.

\subsection{Emulsifying properties}

Emulsifying activity and emulsion stability were determined as described by Neto, Narain, Silva, and Bora (2001). Five milliliters protein solution $(0.5 \mathrm{mg} / \mathrm{ml})$ was homogenized with $5 \mathrm{ml}$ sunflower oil for $60 \mathrm{~s}$ at $1000 \mathrm{rpm}$ by using an homogenizer (Ultra Turrax IKA T18 Basic, Germany). The emulsion was centrifuged at $1100 \mathrm{x}$ $\mathrm{g}$ for $5 \mathrm{~min}$ and the height of the emulsified layer was recorded. The emulsifying activity was calculated as a ratio of the height of the emulsified layer and the height of the total content of the tube and multiplied by 100 to express in percent. Emulsion stability was established after heating. Therefore, hereafter emulsion stability should be considered as emulsion heat stability. The protein emulsion was heated up to $80^{\circ} \mathrm{C}$ in a waterbath (WNB 29, Memmert GmbH + Co.KG, Ger- many) and kept under the same conditions for 30 min. It was subsequently cooled down to room temperature $\left(22^{\circ} \mathrm{C}\right)$ and centrifuged at $1100 \mathrm{x} \mathrm{g}$ for 5 min. Emulsion stability was calculated by the height of emulsified layer after heating divided by the height of the emulsified layer before heating and multiplied by 100 to express in percent. $\mathrm{NaCl}$ was added to a test system to reach a final concentration of either $0.03 \mathrm{M}$ or $0.25 \mathrm{M}$ as appropriate. The influence of $\mathrm{pH}$ on foaming and emulsifying properties was tested by varying $\mathrm{pH}$ from 2 to 10 with an increment of 2 using $\mathrm{NaOH}$ or $\mathrm{HCl}$.

\subsection{Statistical analysis}

The data are presented as means of results obtained from two independent experiments \pm standard deviations. They were analyzed by oneway analysis of variance (ANOVA) using Statgraphics Centurion (version XVI, 2009) statistical program (Stat Point Technologies, Ins., Warrenton, VA, USA). Mean differences were established by Fisher's least significant difference test for paired comparison with a significance level $\alpha$ $=0.05$.

\section{Results and Discussion}

\subsection{WAC and OAC of protein isolates}

Vegetable protein for food applications is an alternative to animal protein and represents a significant contribution to human dietary protein intake (Moure et al., 2006). The sunflower meal protein isolates, analyzed in the current study, are rich in sulfur-containing amino acids and arginine and exhibit sufficient water solubility over a wide $\mathrm{pH}$ range as previously established in our laboratory (Ivanova, Chalova, Koleva, Pishtiyski, et al., 2013).

Water/oil absorption capacity is the ability of proteins to absorb and retain liquid which influences texture and mouth feel characteristics of food products (Okezie \& Bello, 1988). In our study, the WAC of PI1 $(8.57 \pm 0.40 \mathrm{~g} / \mathrm{g})$ was approximately 6 fold higher than the WAC of PI2 $(1.42 \pm 0.04 \mathrm{~g} / \mathrm{g})$ (Table 1$)$. It was 
206 | Ivanova et al.

Table 1: Water and oil absorption capacity of protein isolate 1 and protein isolate 2 at different concentrations of $\mathrm{NaCl}$

\begin{tabular}{lcccccc}
\hline & \multicolumn{2}{c}{ Water absorption capacity, g $\mathrm{H}_{2} \mathrm{O} / \mathrm{g}$ protein } & \multicolumn{3}{c}{ Oil absorption capacity, g oil/g protein } \\
\cline { 2 - 6 } & \multicolumn{3}{c}{ NaCl concentrations, M } & \multicolumn{3}{c}{ NaCl concentrations, M } \\
\cline { 2 - 6 } & 0.00 & 0.03 & 0.25 & 0.00 & 0.03 & 0.25 \\
\hline Protein isolate 1 & $8.57 \pm 0.40^{a}$ & $5.81 \pm 0.17^{b}$ & $2.48 \pm 0.04^{c}$ & $1.41 \pm 0.04^{a}$ & $1.78 \pm 0.03^{a}$ & $1.49 \pm 0.24^{a}$ \\
Protein isolate 2 & $1.42 \pm 0.04^{a}$ & $1.45 \pm 0.11^{a}$ & $1.62 \pm 0.16^{a}$ & $1.12 \pm 0.01^{a}$ & $1.15 \pm 0.33^{a}$ & $1.37 \pm 0.17^{a}$ \\
\hline
\end{tabular}

${ }^{a-c}$ Means in a row for a particular functional property with common superscripts do not differ significantly $(\mathrm{p} \geq 0.05)$

comparable to the WAC of commercial soybean protein isolates such as Purina Protein 500E $(7.9 \mathrm{ml} / \mathrm{g})$ and $760(8.8 \mathrm{ml} / \mathrm{g})$, and Protein$\max 90 \mathrm{HE}(8.4 \mathrm{ml} / \mathrm{g})$ (Zayas, 1997). The WAC of PI2 was close to the WAC of a meal prepared from mixed sunflower cultivars (Rahaman, Ahmed, Babiker, \& Mahgoub, 2006) and some plant proteins such as cashew nut protein concentrate $(1.74 \mathrm{ml} / \mathrm{g}$ ) (Ogunwolu, Henshaw, Mock, Santros, \& Awonorin, 2009) and jojoba protein concentrate (Wiseman \& Price, 1987).

Statistical differences in the WAC of PI1 and PI2 were also observed when studied in the presence of $\mathrm{NaCl}$. $\mathrm{NaCl}$ is a common ingredient used in food industry to enhance flavour, preserve food, and improve processing but is a strong modulator of protein functionality (Aremu et al., 2008; Andualem \& Gessesse, 2013). In our study, the functional properties of the protein isolates were studied at two levels of $\mathrm{NaCl}$, namely $0.03 \mathrm{M}$ and $0.25 \mathrm{M}$, which corresponded to the most common boundary concentrations of $\mathrm{NaCl}$ used in the preparation of commercial food products. According to (Dragoev, Vulkova-Yorgova, \& Balev, 2008), $\mathrm{NaCl}$ content of different type unprocessed meat may vary from $0.16 \%$ to $0.25 \%$. (Antova \& Georgieva, 2008) reported that commercial butter contained $0.1 \%$ to $0.2 \% \mathrm{NaCl}$. Higher $\mathrm{NaCl}$ concentrations are allowed for application in bread $(1.2 \%)$ and processed meat products (2.0\%) (BDS 3412, 1979; BDS 7168, 1993).

Both levels of $\mathrm{NaCl}(0.03 \mathrm{M}$ and $0.25 \mathrm{M})$ influenced the WAC of PI1 as the addition of 0.25 $\mathrm{M} \mathrm{NaCl}$ leaded to more than 3 fold decrease of the WAC when compared to the WAC of the isolate in water. Although to a smaller extent, increases of $\mathrm{NaCl}$ concentrations diminished the WAC of groundnut protein (Aremu et al., 2008). In contrast, no statistical differences in WAC of PI2 were established after supplementation with $\mathrm{NaCl}$ (Table 1). The differences in the WAC of PI1 and PI2 may be due to the purity and protein content of the two protein isolates. PI1 contained $94.25 \%$ protein and $1.34 \%$ ash, while PI2 was characterized with lower protein $(75.34 \%)$ and higher ash content $(13.26 \%)$. The amount of total charbohydrates of PI2 (4.56\%) exceeded the amount of total charbohydrates established in PI1 (1.74\%). In contrast, a higher content of total lipids $(2.60 \%)$ was found in PI1 when compared to PI2 (1.50\%) (Ivanova et al., 2011). According to Kinsella et al. (1985), the presence of non-protein components may impair protein unfolding and the exposure of additional binding sites to water molecules thus diminishing their WAC.

In contrast to WAC, OAC of PI1 $(1.41 \pm 0.04$ $\mathrm{g} / \mathrm{g})$ and PI2 $(1.12 \pm 0.01 \mathrm{~g} / \mathrm{g})$ were found to be similar (Table 1). They were close to the OAC of a soy protein isolate $(1.3 \pm 0.02 \mathrm{~g} / \mathrm{g})$ established by Alkahtani and Abouarab (1993) but lower than the data reported by L'Hocine, Boye, and Arcand (2006). According to the latter, the $\mathrm{OAC}$ of soy isolates may reach $9 \mathrm{~g} / \mathrm{g}$ depending on pre-treatment of the seeds and the methods used for the preparation of the protein isolates. $\mathrm{NaCl}$ did not affect the OAC of either PI1 or PI2 $(\mathrm{p} \geq 0.05)$. 
Functional properties of sunflower meal protein isolates $\mid 207$

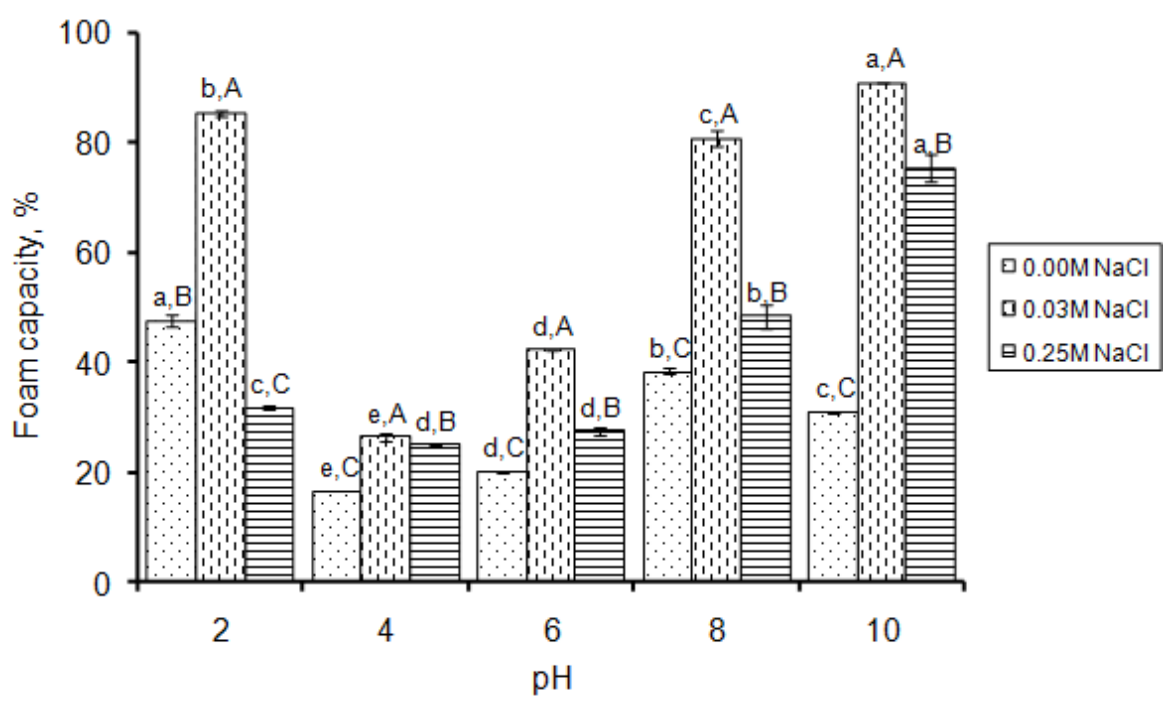

Figure 1: Foam capacity of protein isolate 1 at different $\mathrm{pH}$ and $\mathrm{NaCl}$ concentrations.

$a-e$ Means with same lowercase letter for a particular $\mathrm{NaCl}$ concentration do not differ significantly $(\mathrm{p} \geq 0.05)$.

$A-C$ Means with same capital letter for a particular $\mathrm{pH}$ value do not differ significantly $(\mathrm{p} \geq 0.05)$.

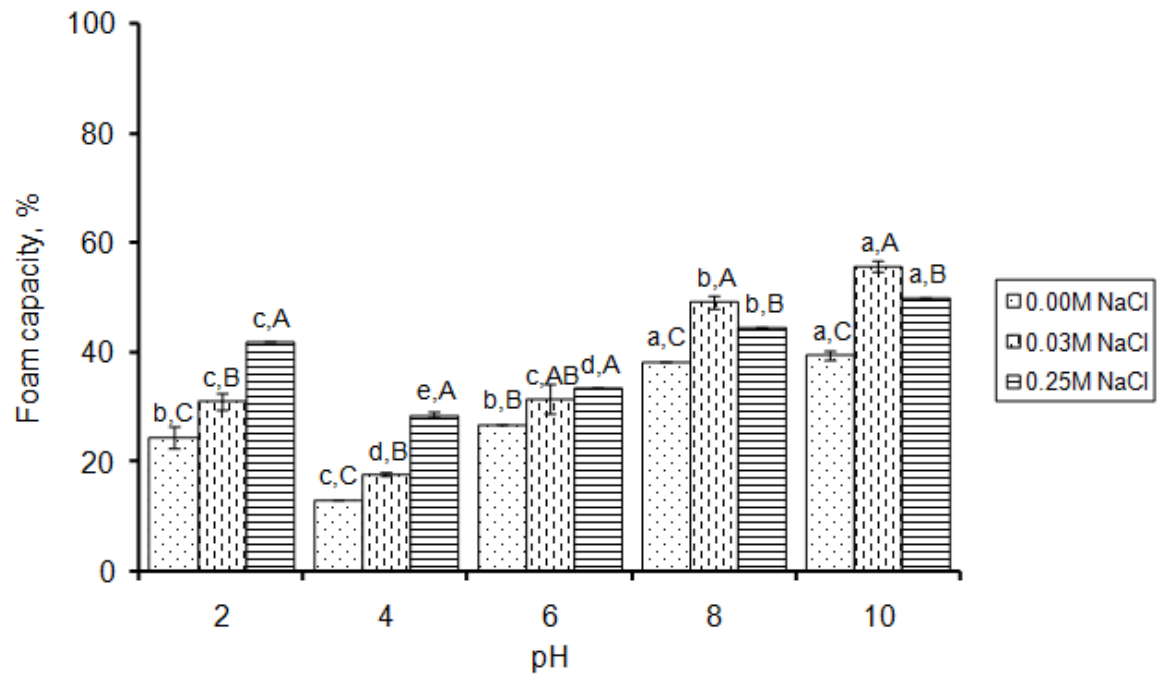

Figure 2: Foam capacity of protein isolate 2 at different $\mathrm{pH}$ and $\mathrm{NaCl}$ concentrations.

$a-c$ Means with same lowercase letter for a particular $\mathrm{NaCl}$ concentration do not differ significantly $(\mathrm{p} \geq 0.05)$.

$A-C$ Means with same capital letter for a particular $\mathrm{pH}$ value do not differ significantly $(\mathrm{p} \geq 0.05)$. 


\subsection{Foaming properties of PI1 and $\mathrm{PI} 2$ at different $\mathrm{pH}$}

Variations in $\mathrm{pH}$ influenced the foam capacity of both protein isolates either in the presence of $\mathrm{NaCl}$ or without salt (Fig. 1 and Fig. 2). In general, the trend followed $\mathrm{pH}$-dependent solubility of the protein isolates previously established in our laboratory (Ivanova et al., 2013). A similar observation was reported by Khalil, Ragab, and Hassanien (1985) who studied the functional properties of proteins isolated from oilseeds.

The foam capacity of PI1 was the lowest at $\mathrm{pH}$ 4 under all tested conditions (Fig. 1). Without addition of $\mathrm{NaCl}$, the alteration was more prominent at $\mathrm{pH} 2$ where approximately 3 fold increase of the foam capacity was observed. According to González-Pérez et al. (2004), the smaller foam volume of sunflower proteins in neutral or alkaline media is due to the relatively large molecules and stable conformation of helianthinin which impair their absorption at system interfaces. In acidic medium $(\mathrm{pH}<3)$, globulins dissociate to monomers which increases the volume of the foam.

Foam capacity of PI2 was also $\mathrm{pH}$ dependent (Fig. 2). However, in contrast to PI1, it reached maximal values at $\mathrm{pH} 8$ and 10 which corresponded to the solubility profile of the isolate under the conditions studied (Ivanova et al., 2013). The presence of $\mathrm{NaCl}$ improved the foam capacity of both protein isolates (Fig. 1 and 2). However, the influence of the lower concentration of $\mathrm{NaCl}(0.03 \mathrm{M})$ on the foam capacity of PI1 was stronger than that of the higher $\mathrm{NaCl}$ concentration $(0.25 \mathrm{M})$ (Fig. 1). In general, the influence of $\mathrm{NaCl}$ on foam capacity of PI1 and PI2 followed the solubility pattern of the protein isolates at different $\mathrm{pH}$ values (Ivanova et al., 2013). At the $\mathrm{pH}$ corresponding to high solubility of protein isolates, the influence of $\mathrm{NaCl}$ on the foam capacity was stronger than that at the $\mathrm{pH}$ providing conditions for low solubility of the isolates. The foam stability of PI1 and PI2 is presented in Table 2. The minimum foam stability of both isolates in water without addition of $\mathrm{NaCl}$ was observed at $\mathrm{pH} 4$. Both levels of $\mathrm{NaCl}$ improved the foam stability of PI1 and PI2 at pH 4 only. For all other $\mathrm{pH}$ values, the addition of either 0.03
$\mathrm{M}$ or $0.25 \mathrm{M} \mathrm{NaCl}$ diminished the foam stability with the exception of $\mathrm{pH} 2$ where $0.25 \mathrm{M} \mathrm{NaCl}$ improved the foam stability of PI1 to $91.51 \pm$ $3.70 \%$. These results are probably a consequence of the influence of $\mathrm{pH}$ and $\mathrm{NaCl}$ on protein molecular charge and interactions. At the isoelectric point of the sunflower proteins $(\mathrm{pH} 4)$, the total charge of protein molecules is close to zero which leads to their aggregation and coagulation. The higher molecular weight complexes impair the formation of viscoelastic protein film at the boundary of the two phases which is mandatory for stabilization of the foam. At $\mathrm{pH}$ values differing from the $\mathrm{pH}$ of the isoelectric point, the protein molecules are either positively or negatively charged which determines their electrostatic repulsion. $\mathrm{NaCl}$ exhibits a similar influence on protein molecules. Chloride anions neutralize the positive charge of protein molecules thus moving isoelectric point to lower $\mathrm{pH}$ values. As a result, the addition of $\mathrm{NaCl}$ leads to a balance between protein-protein and protein-water interactions and the formation of a net-like structure at the interface which improves the foam stability at $\mathrm{pH}$ 4. In alkaline media, where protein molecules are negatively charged, the addition of $\mathrm{NaCl}$ increases electrostatic repulsion of proteins which forms an unstable boundary protein layer (Schnepf, 1992; Damodaran, 1997).

\subsection{Emulsifying properties of protein isolates}

The ability to form and stabilize emulsions is an important functional characteristic of sunflower protein isolates when used as food ingredients (Pawar et al., 2001). The emulsifying activity of PI1 and PI2 as a function of $\mathrm{pH}$ at two different levels of $\mathrm{NaCl}(0.03 \mathrm{M}$ and $0.25 \mathrm{M})$ is presented in Table 3. Both protein isolates expressed minimum emulsifying activity at $\mathrm{pH} 4$. Lowest emulsifying activity of protein isolates in the $\mathrm{pH}$ area of the isoelectric point was reported by Mao and Hua (2012) and Ogunwolu et al. (2009) who studied the functional properties of walnut and cashew nut proteins respectively. According to Damodaran (1997), most plant proteins are poor emulsifiers at the $\mathrm{pH}$ around their isoelectric points due to the low level of hydra- 
Functional properties of sunflower meal protein isolates $\mid 209$

Table 2: Influence of $\mathrm{pH}$ on foam stability of protein isolate 1 and protein isolate 2

\begin{tabular}{|c|c|c|c|c|c|c|}
\hline & \multirow{3}{*}{$\mathrm{NaCl}, \mathrm{M}$} & \multicolumn{5}{|c|}{ Foam stability, \% } \\
\hline & & \multicolumn{5}{|c|}{$\mathrm{pH}$} \\
\hline & & 2 & 4 & 6 & 8 & 10 \\
\hline \multirow{3}{*}{ Protein isolate 1} & 0.00 & $82.18 \pm 0.25^{b c, B}$ & $50.00 \pm 0.00^{d, B}$ & $98.13 \pm 0.88^{a, A}$ & $84.22 \pm 2.11^{b, A}$ & $81.54 \pm 0.40^{c, A}$ \\
\hline & 0.03 & $50.84 \pm 1.18^{b, C}$ & $89.29 \pm 5.06^{a, A}$ & $80.74 \pm 4.91^{a, B}$ & $56.79 \pm 4.55^{b, C}$ & $50.00 \pm 0.00^{b, C}$ \\
\hline & 0.25 & $91.51 \pm 3.70^{a, A}$ & $58.57 \pm 2.02^{d, B}$ & $84.93 \pm 0.44^{b, B}$ & $68.93 \pm 1.51^{c, B}$ & $57.78 \pm 3.14^{d, B}$ \\
\hline \multirow{3}{*}{ Protein isolate 2} & 0.00 & $82.38 \pm 1.34^{c, A}$ & $66.67 \pm 0.00^{d, B}$ & $85.71 \pm 0.00^{b, A}$ & $91.49 \pm 0.26^{a, A}$ & $84.26 \pm 1.32^{b c, A}$ \\
\hline & 0.03 & $74.17 \pm 1.18^{a, B}$ & $77.50 \pm 3.54^{a, A}$ & $76.39 \pm 1.97^{a, B}$ & $74.78 \pm 4.74^{a, B}$ & $73.61 \pm 1.97^{a, B}$ \\
\hline & 0.25 & $72.73 \pm 0.00^{c d, B}$ & $79.52 \pm 2.45^{a, A}$ & $77.78 \pm 0.00^{a b, B}$ & $75.00 \pm 0.00^{b c, B}$ & $70.00 \pm 0.00^{d, B}$ \\
\hline
\end{tabular}

${ }^{a-d}$ Means in a row with same lowercase letter do not differ significantly ( $\left.\mathrm{p} \geq 0.05\right)$.

$A-C$ Means in a column for a particular protein isolate with same capital letter do not differ significantly $(\mathrm{p} \geq 0.05)$.

Table 3: Influence of $\mathrm{pH}$ on emulsifying activity of protein isolate 1 and protein isolate 2

\begin{tabular}{lcccccc}
\hline & \multicolumn{5}{c}{ Emulsifying activity, \% } \\
\cline { 3 - 7 } & NaCl, M & \multicolumn{5}{c}{$\mathrm{pH}$} \\
\cline { 3 - 7 } & & 2 & 6 & 6 & 10 \\
\hline \multirow{2}{*}{ Protein isolate 1 } & 0.00 & $52.90 \pm 2.55^{a, A}$ & $44.75 \pm 1.77^{b, A}$ & $53.66 \pm 3.67^{a, A}$ & $54.53 \pm 3.44^{a, A}$ & $55.75 \pm 3.47^{a, A}$ \\
& 0.03 & $57.14 \pm 0.00^{a, A}$ & $45.45 \pm 2.40^{c A}$ & $51.40 \pm 2.86^{b, A}$ & $54.13 \pm 2.02^{a b, A}$ & $58.77 \pm 0.62^{a, A}$ \\
Protein isolate 2 & 0.25 & $53.70 \pm 1.19^{b, A}$ & $2.90 \pm 0.06^{c, B}$ & $55.20 \pm 1.62^{b, A}$ & $53.69 \pm 0.51^{b, A}$ & $59.17 \pm 1.18^{a, A}$ \\
& 0.00 & $49.00 \pm 1.41^{a b, B}$ & $45.85 \pm 1.20^{b, B}$ & $52.70 \pm 0.28^{a, B}$ & $51.30 \pm 1.84^{a, A}$ & $51.55 \pm 3.18^{a, B}$ \\
& 0.03 & $58.22 \pm 0.35^{a, A}$ & $47.62 \pm 1.35^{c, B}$ & $53.10 \pm 0.34^{b, B}$ & $53.33 \pm 0.00^{b, A}$ & $59.57 \pm 1.75^{a, A}$ \\
& 0.25 & $60.88 \pm 1.25^{a, A}$ & $53.00 \pm 1.34^{c, A}$ & $55.63 \pm 0.52^{b c, A}$ & $53.59 \pm 0.36^{c, A}$ & $57.17 \pm 1.65^{b, A B}$ \\
\hline
\end{tabular}

${ }^{a-c}$ Means in a row with same lowercase letter do not differ significantly ( $\left.\mathrm{p} \geq 0.05\right)$.

$A-B$ Means in a column for a particular protein isolate with same capital letter do not differ significantly ( $\mathrm{p} \geq 0.05)$.

Table 4: Influence of $\mathrm{pH}$ on emulsion stability of protein isolate 1 and protein isolate 2

\begin{tabular}{lcccccc}
\hline & & \multicolumn{5}{c}{ Emulsion stability, \% } \\
\cline { 3 - 7 } & \multirow{n}{nyyyyy}{} & NaCl, M & \multicolumn{5}{c}{$\mathrm{pH}$} \\
\cline { 3 - 7 } & & 2 & 4 & 6 & 8 & 10 \\
\hline \multirow{3}{*}{ Protein isolate 1 } & 0.00 & $93.20 \pm 2.69^{b c, B}$ & $100.0 \pm 0.00^{a, A}$ & $90.30 \pm 1.98^{c, B}$ & $95.75 \pm 0.21^{b, A}$ & $93.65 \pm 0.21^{b c, B}$ \\
& 0.03 & $100.0 \pm 0.00^{a, A}$ & $93.67 \pm 3.90^{a, A}$ & $100.0 \pm 0.00^{a, A}$ & $97.44 \pm 3.63^{a, A}$ & $98.81 \pm 1.68^{a, A}$ \\
Protein isolate 2 & 0.25 & $100.0 \pm 0.00^{a, A}$ & $100.0 \pm 0.00^{a, A}$ & $92.50 \pm 0.00^{c, B}$ & $96.25 \pm 1.77^{b, A}$ & $96.43 \pm 1.68^{b, A B}$ \\
& 0.00 & $100.0 \pm 0.00^{a, A}$ & $98.55 \pm 2.05^{a b, A}$ & $98.65 \pm 1.91^{a b, A}$ & $100.0 \pm 0.00^{a, A}$ & $96.25 \pm 1.34^{b, B}$ \\
& 0.03 & $100.0 \pm 0.00^{a, A}$ & $86.97 \pm 1.78^{b, B}$ & $100.0 \pm 0.00^{a, A}$ & $98.75 \pm 1.77^{a, A}$ & $100.0 \pm 0.00^{a, A}$ \\
& 0.25 & $97.62 \pm 3.37^{a, A}$ & $98.78 \pm 1.72^{a, A}$ & $97.62 \pm 3.37^{a, A}$ & $98.81 \pm 1.68^{a, A}$ & $95.24 \pm 0.00^{a, B}$ \\
\hline
\end{tabular}

${ }^{a-c}$ Means in a row with same lowercase letter do not differ significantly ( $\left.\mathrm{p} \geq 0.05\right)$.

$A-B$ Means in a column for a particular protein isolate with same capital letter do not differ significantly $(\mathrm{p} \geq 0.05)$. 
tion and lack of electrostatic repulsive forces. At $\mathrm{pH}$ values differing from 4 , the emulsifying activity of PI1 and PI2 varied from $45 \%$ to $60 \%$. $\mathrm{NaCl}$ did not influence the emulsifying activity of $\mathrm{PI} 1$ at all $\mathrm{pH}$ values with except at $\mathrm{pH} 4$ where it was highly reduced to $2.90 \pm 0.06$ by the addition of $0.25 \mathrm{M} \mathrm{NaCl}$. The emulsifying activity of PI2 was enhanced by the higher level $\mathrm{NaCl}$. Improvement of the emulsifying activity of the isolate by $0.03 \mathrm{M} \mathrm{NaCl}$ was reached only at $\mathrm{pH} 2$ and $\mathrm{pH} 10$ when compared to water. In general, the protein isolates formed emulsions which remained stable (>90\%) under all studied conditions (Table 4). Mahajan and Dua (2002) also reported that salts, $\mathrm{NaCl}$ and $\mathrm{NaHCO}_{3}$, did not change the emulsifying properties of amaranth seed meal. Stable emulsion properties of sunflower protein isolate were reported by González-Pérez et al. (2005) as well.

\section{Conclusions}

As a whole, the $\mathrm{pH}$ and $\mathrm{NaCl}$, at the concentrations studied, influenced foam properties and emulsifying activity of PI1 and PI2. They slightly altered the emulsion stability of the isolates which remained above $90 \%$ under all studied conditions. $\mathrm{NaCl}$ significantly influenced the WAC of PI1 but not that of PI2 or the OAC of both isolates. The significant differences between PI1 and PI2 observed for a particular functional property were probably due to physico-chemical characteristics of the isolates which originated in the specifics of the methods for their preparations. Knowledge of the influence of $\mathrm{pH}$ and boundary concentrations of $\mathrm{NaCl}$ on the functionality of sunflower meal protein isolates could be beneficial for their future potential application in food formulation.

\section{References}

Ahmedna, M., Prinyawiwatkul, W., \& Rao, R. M. (1999). Solubilized wheat protein isolate: functional properties and potential food applications. Journal of Agricultural and Food Chemistry, 47(4), 13401345. doi:10.1021/jf981098s
Alkahtani, H. A. \& Abouarab, A. A. (1993). Comparison of physical, chemical, and functional-properties of moringa-peregrina (al-yassar or al-ban) and soybean proteins. Cereal Chemistry, 70(6), 619-626.

Andualem, B. \& Gessesse, A. (2013). Effects of Salt $(\mathrm{NaCl})$ Concentrations on the Functional Properties of Defatted Brebra (Millettia ferruginea) Seed Flour. Middle-East Journal of Scientific Research, 13(7), 889897. doi:10.5829/idosi . mejsr . 2013 . 13.7. 2791

Antova, T., G. andNenkova \& Georgieva, L. (2008). Comparative investigation of trade marks butter. Scientific Papers, 36(5), 111-117. Retrieved from http://argon.uniplovdiv .bg / files / 2008/03/014_NT36 2008.pdf

Aremu, M. O., Olaofe, O., Akintayo, E. T., \& Adeyeye, E. I. (2008). Foaming, water absorption, emulsification and gelation properties of kersting's groundnut (Kerstingiella geocarpa) and bambara groundnut (Vigna subterranean) flours as influenced by neutral salts and their concentrations. Pakistan Journal of Nutrition, 7(1), 194-201.

Bau, H. M., Mejean, L., Debry, G., \& Mohtadinia, D. J. (1983). Preparation of colorless sunflower protein products - effect of processing on physicochemical and nutritional properties. Journal of the American Oil Chemists Society, 60(6), 1141-1148. doi:10.1007/BF02671343

BDS 3412. (1979). Bread and bakery products. rules for sampling and methods for testing.

BDS 7168. (1993). Processed fruit, vegetables and meat. canned meat and meatvegetables. methods for determination of chlorides.

Damodaran, S. (1997). Food proteins: An overview (Food Proteins and Their Applications (pp. 1-21)) (S. Damodaran \& A. Paraf, Ed.). New York: Marcel Dekker.

Dragoev, S. G., Vulkova-Yorgova, K. I., \& Balev, D. K. (2008). Technology of functional and special meat and fish products. Sofia: Minerva.

González-Pérez, S., vavan Koningsveld, G. A., Vereijken, J. M., Merck, K. B., Gruppen, 
Functional properties of sunflower meal protein isolates |211

H., \& Voragen, A. G. J. (2005). Emulsion properties of sunflower (Helianthus annuus) proteins. Journal of Agricultural and Food Chemistry, 53(6), 2261-2267. doi:10. 1021/jf0486388

González-Pérez, S., Vereijken, J. M., Merck, K. B., Van Koningsveld, G. A., Gruppen, H., \& Voragen, A. G. J. (2004). Conformational states of sunflower (Helianthus annuus) helianthinin: effect of heat and ph. Journal of Agricultural and Food Chemistry, 52(22), 6770-6778. doi:10 . 1021 jf0459612j

Ivanova, P., Chalova, V., Koleva, L., Pishtiyski, I., et al. (2013). Amino acid composition and solubility of proteins isolated from sunflower meal produced in bulgaria. International Food Research Journal, 20(6), 29953000.

Ivanova, P., Chalova, V., Koleva, L., Pishtiyski, I., \& Perifanova-Nemska, M. (2012). Optimization of protein extraction from sunflower meal produced in bulgaria. Bulgarian Journal of Agricultural Science, 18(2), 153-160.

Ivanova, P., Koleva, L., Tziporkov, N., \& Pishtiyski, I. (2011). Isolation of proteins from salt extracts of sunflower meal. $S W$ UFT-Plovdiv LVIII, 2, 391-396.

Kanu, P. J., Kerui, Z., Ming, Z. H., Haifeng, Q., Kanu, J. B., \& Kexue, Z. (2007, May). Sesame protein 11: functional properties of sesame (Sesamum indicum L.) protein isolate as influenced by ph, temperature, time and ratio of flour to water during its production. Asian Journal of Biochemistry, 2(5), 289-301. doi:10.3923/ajb.2007.289. 301

Khalil, M., Ragab, M., \& Hassanien, F. R. (1985). Some functional-properties of oilseed proteins. Nahrung-Food, 29(3), 275-282.

Kinsella, J. E., Damodaran, S., \& German, B. (1985). Physicochemical and functional properties of oilseed proteins with emphasis on soy proteins. New protein foods (USA), 5, 107-179.

L'Hocine, L., Boye, J. I., \& Arcand, Y. (2006). Composition and functional properties of soy protein isolates prepared using alterna- tive defatting and extraction procedures. Journal of Food Science, 71(3), C137C145.

Lin, C. S. \& Zayas, J. F. (1987). Functionality of defatted corn germ proteins in a model system: fat binding capacity and water retention. Journal of Food Science, 52(5), 1308-1311. doi:10.1111/j.1365-2621.1987. tb14070.x

Mahajan, A. \& Dua, S. (2002). Salts and ph induced changes in functional properties of amaranth (Amaranthus tricolor 1.) seed meal. Cereal Chemistry, 79(6), 834-837. doi:10.1094/CCHEM.2002.79.6.834

Mao, X. \& Hua, Y. (2012). Composition, structure and functional properties of protein concentrates and isolates produced from walnut (juglans regia l.) International Journal of Molecular Sciences, 13(2), 1561-1581. doi:10.3390/ijms13021561

Martínez-Maqueda, D., Hernández-Ledesma, B., Amigo, L., Miralles, B., \& Gómez-Ruiz, J. Á. (2013). Extraction/fractionation techniques for proteins and peptides and protein digestion (Proteomics in Foods: Principles and Application (pp. 21-50)) (F. Toldrá \& L.M.L. Nollet, Ed.). New York: Springer Science \& Business Media.

Moure, A., Sineiro, J., Dominguez, H., \& Parajo, J. C. (2006). Functionality of oilseed protein products: a review. Food Research International, 39(9), 945-963. doi:10.1016/j. foodres.2006.07.002

Neto, V. Q., Narain, N., Silva, J. B., \& Bora, P. S. (2001). Functional properties of raw and heat processed cashew nut (Anacardium occidentale, l.) kernel protein isolates. Nahrung-Food, 45(4), 258262. doi:10.1002/1521-3803(20010801) 45: $4<258:$ :AID-FOOD258>3.0.CO;2-3

Ogunwolu, S. O., Henshaw, F. O., Mock, H.-P., Santros, A., \& Awonorin, S. O. (2009). Functional properties of protein concentrates and isolates produced from cashew (Anacardium occidentale 1.) nut. Food Chemistry, 115(3), 852-858. doi:10.1016/j. foodchem.2009.01.011

Okezie, B. O. \& Bello, A. B. (1988). Physicochemical and functional-properties of winged bean flour and isolate compared 
with soy isolate. Journal of Food Science, 53(2), 450-454. doi:10.1111/j.1365-2621. 1988.tb07728.x

Pawar, V. D., Patil, J. N., Sakhale, B. K., \& Agarkar, B. S. (2001). Studies on selected functional properties of defatted sunflower meal and its high protein products. Journal of Food Science and Technology-Mysore, $38(1), 47-51$.

Pickardt, C., Neidhart, S., Griesbach, C., Dube, M., Knauf, U., Kammerer, D. R., \& Carle, R. (2009). Optimisation of mild-acidic protein extraction from defatted sunflower (Helianthus annuus 1.) meal. Food Hydrocolloids, 23(7), 1966-1973. doi:10.1016/j . foodhyd.2009.02.001

Rahaman, S. M. A., Ahmed, I. A. M., Babiker, E. E., \& Mahgoub, S. A. (2006). Composition, total protein structure and physicochemical properties of meals prepared from sunflower (Helianthus annuus L.) cultivars. Journal of Food Technology, 4, 22-28. Retrieved from http://medwelljournals.com/ abstract/?doi=jftech.2006.22.28

Raza, S., Ashraf, M., Pasha, T. N., \& Latif, F. (2009). Effect of enzyme supplementation of broiler diets containing varying level of sunflower meal and crude fiber. Pakistan Journal of Botany, 41(5), 2543-2550.

Rodríguez-Ambriz, S. L., Martínez-Ayala, A. L., Millán, F., \& Dávila-Ortíz, G. (2005). Composition and functional properties of Lupinus campestris protein isolates. Plant Foods for Human Nutrition, 60(3), 99-107. doi:10.1007/s11130-005-6835-Z

Schnepf, M. I. (1992). Protein-water interactions. In B. Hudson (Ed.), Biochemistry of food proteins (pp. 1-33). Springer US. doi:10. 1007/978-1-4684-9895-0_1

Senkoylu, N. \& Dale, N. (2006). Nutritional evaluation of a high-oil sunflower meal in broiler starter diets. Journal of Applied Poultry Research, 15(1), 40-47.

Sze-Tao, K. W. C. \& Sathe, S. K. (2000). Functional properties and in vitro digestibility of almond (Prunus dulcis 1.) protein isolate. Food Chemistry, 69(2), 153-160. doi:10.1016/S0308-8146(99)00244-7

Wiseman, M. O. \& Price, R. I. (1987). Functional-properties of protein- concentrates from pressed jojoba meal. Cereal Chemistry, 64(2), 94-97.

Zayas, J. F. (1997). Solubility of proteins. In Functionality of proteins in food (pp. 675). Berlin, Germany: Springer-Verlag. 